\title{
The Role of Agrotechnical Factors in Shaping the Health of Maize Plants (Zea mays L.)
}

\author{
Piotr Szulc ${ }^{1 *}$, Katarzyna Ambroży-Deręgowska², Iwona Mejza², \\ Joanna Kobus-Cisowska ${ }^{3}$, Marta Ligaj ${ }^{4}$, Daniel Krauklis ${ }^{1}$ \\ ${ }^{1}$ Department of Agronomy, Poznań University of Life Sciences, Dojazd 11, 60-632 Poznań, Poland \\ ${ }^{2}$ Department of Mathematical and Statistical Methods, Poznań University of Life Sciences, \\ Wojska Polskiego 28, 60-637 Poznań, Poland \\ ${ }^{3}$ Poznań University of Life Sciences, Department of Gastronomy Sciences and Functional Foods, \\ Wojska Polskiego 31, 60-624, Poznań, Poland \\ ${ }^{4}$ Department of Industrial Products and Packaging Quality, Poznań University of Economics and Business, \\ al. Niepodległości 10, 61-875 Poznań, Poland
}

Received: 27 March 2020

Accepted: 14 May 2020

\begin{abstract}
The article presents the results of 3-year field studies, whose purpose was to assess the impact of maize sowing method, type of cultivar and NP fertiliser sowing method on the health of maize plants. Changing weather conditions during the study years significantly differentiated the percentage of maize plants damaged by pests and affected by diseases. The positive effect of the row method of NP fertiliser application in maize cultivation not only reduced plant infestation by Fusarium diseases, but also reduced Frit fly (Oscinella frit L.) pressure. The "stay-green" hybrid was characterized by a significantly lower susceptibility to feeding of the European corn borer (Ostrinia nubilalis Hbn.) compared to the traditional cultivar. Sowing maize of the traditional cultivar using the direct sowing system increased damage to plants caused by Frit fry larvae (Oscinella frit L.) compared to sowing into soil cultivated in a traditional way. For the "stay-green" type, the method of soil preparation for sowing did not significantly affect the pressure of this pest. A simplified method of soil preparation for sowing maize should give preference to cultivating "stay-green" varieties.
\end{abstract}

Keywords: Zea mays L., agrophage, agricultural practices

\section{Introduction}

Repetitive water shortages occurring almost every year in the maize growing season incline to search

*e-mail: piotr.szulc@up.poznan.pl for agrotechnical solutions aimed at counteracting this unfavorable situation [1, 2]. Agrotechnical treatments can result in a permanent aggregate structure formation, which promotes optimal physical conditions in the soil, preventing its excessive compaction. This ensures a favorable content of capillary pores, enabling water access to plant roots [3, 4]. In addition, stable and waterproof aggregate structure prevents soil crusting, increasing its capacity to rainwater absorption [5]. 
Soil density is a property that depends on mineral and granulometric composition of soil material, organic matter content, soil structure and agrotechnical treatments [6]. It is considered to be an indirect indicator of soil structure, compactness, porosity, aeration and soil capacity to store and transport soil water [7]. Proper fertilization of plants is also very important in integrated maize protection against diseases and pests [8-10]. It not only determines the size of the yield, but also increases plant tolerance to disease infestation and pest feeding. This has been confirmed by Krauss [11], according to whom the degree of pest pressure on a crop is the resultant of its nutritional status. Therefore, the search for alternative methods to reduce the impact of pests on arable crops is such an important element of agronomic works [12]. For this reason, creating hybrids with traits that give them an advantage in an environment with limited water resources is one of the main challenges facing the breeding of new varieties [13]. Breeding in the direction of better plant health later in the growing season or "stay-green" varieties may be the solution [14]. This feature is an indicator of higher plant health in the later vegetation period, reduced progressive aging and drought tolerance after flowering $[15,16]$. In integrated plant protection programs, it is extremely important to select varieties for cultivation that, on the one hand, are adapted to local soil and climate conditions, and on the other hand, are less susceptible to pests [17]. Therefore, the cultivation of maize "stay-green" varieties can be considered as one of the elements of integrated plant protection, which has been obligatory in the European Union since January 1, 2014. This issue is very important from the point of view of integrated plant protection, which particularly prefers the use of non-chemical methods, including the selection of less susceptible to damage or infestation varieties for cultivation. These studies are also important in the context of the observed climate changes that affect both the crop and the organisms damaging it $[1,18,19]$. Hence, the purpose of the field tests was to assess the occurrence of diseases and pests in maize cultivation in the conditions of using different maize sowing methods, selection of varieties and techniques of NP fertiliser application.

\section{Materials and Methods}

\section{Experimental Field}

The field experiment was carried out at the Department of Agronomy of Poznań University of Life Sciences in the years 2012-2014. It was carried out for three years in the same scheme in a split-splitplot design with three factors in 4 field replicates. The study involved the following factors: A - $1^{\text {st }}$ order factor - two methods of maize sowing: A1 - sowing to the soil (traditional cultivation), A2 - direct sowing to the stubble after winter wheat (straw harvested); $B-2^{\text {nd }}$ order factor - two types of varieties: B1 - traditional cultivar SY Cooky, B2 - stay-green cultivar Drim; C $-3^{\text {rd }}$ order factor -2 methods of supplying NP fertiliser: $\mathrm{C} 1$ - broadcast on the entire surface before seed sowing, C2 - in rows simultaneously with seed sowing. The same level of mineral fertilization (100 kg N $\mathrm{ha}^{-1}, 30.8 \mathrm{~kg} \mathrm{Pha}^{-1}$ and $107.9 \mathrm{~kg} \mathrm{~K} \cdot \mathrm{ha}^{-1}$ ) was applied on all experimental objects. Fertilization was balanced against phosphorus, which was applied at the whole required dose in the form of ammonium phosphate under the trade name of polidap NP. N and $\mathrm{K}$ fertilization was performed before maize sowing using urea and potassium salt $(60 \%)$. The $\mathrm{N}$ dose was reduced by the amount of nitrogen present in the polidap. Soil abundance in basic macronutrients before establishing the experiment is presented in Table 1. The magnesium content in the soil was determined by the Schachtschabel method, potassium by the Egner-Riehm method, phosphorus by the Olsen method and $\mathrm{N}_{\text {min }}$ Kjeldahl method. Winter wheat was the forecrop for maize in each year of research. Individual cultivating treatments were carried out in accordance with the adopted schedule within the dates given in Table 2.

\section{Weather Conditions}

Thermal conditions during maize growing in the experimental years were similar to each other and were on average $15.4^{\circ} \mathrm{C}$ in $2012,15.6^{\circ} \mathrm{C}$ in 2013 and $16.1^{\circ} \mathrm{C}$ in the warmest year of 2014. Significantly greater differences between years occurred in the amount of precipitation. The largest sum of rainfall, $473.6 \mathrm{~mm}$, was recorded in 2012, which was $76.2 \mathrm{~mm}$ higher than the precipitation in 2013, and $121.8 \mathrm{~mm}$ higher from the amount of rainfall in 2014. The calculated hydrothermal coefficients of water preservation according to Sielianinow allowed to conclude that weather conditions for the growth and development of maize were moderately beneficial with simultaneous periodic moisture deficits. In 2012, the least amount of rainfall was recorded for April, August and September. A low amount of rainfall combined with a high average air temperature caused a period of insufficient moisture for most plants in these months. In 2001, the months with lowest precipitation were April, July, August and October. This caused the occurrence of acute drought

Table 1. The content of nutrients $(\mathrm{mg} / \mathrm{kg} \mathrm{DM})$ and soil $\mathrm{pH}$ (w $1 \mathrm{~mol} \cdot \mathrm{dm}^{-3} \mathrm{KCl}$ ).

\begin{tabular}{|c|c|c|c|c|}
\hline \multirow{2}{*}{\multicolumn{2}{|c|}{ Specification }} & \multicolumn{3}{|c|}{ Years } \\
\hline & & 2012 & 2013 & 2014 \\
\hline $\mathrm{N}_{\min }$ & $0-60 \mathrm{~cm}$ & 18.4 & 15.9 & 19.9 \\
\hline$P$ & \multirow{4}{*}{$0-25 \mathrm{~cm}$} & 112.0 & 38.0 & 127.0 \\
\hline K & & 95.0 & 111.0 & 261.0 \\
\hline $\mathrm{Mg}$ & & 28.0 & 23.0 & 36.0 \\
\hline $\mathrm{pH}$ & & 4.90 & 4.80 & 4.70 \\
\hline
\end{tabular}


Table 2. Dates of agrotechnical operations.

\begin{tabular}{|c|c|c|c|}
\hline \multirow{2}{*}{ Type of treatment } & \multicolumn{3}{|c|}{ Years } \\
\hline & 2012 & 2013 & 2014 \\
\hline $\begin{array}{l}\text { 1. Deep plowing }(30 \mathrm{~cm}) \\
\text { The treatment was performed in the autumn of the previous year }\end{array}$ & $8^{\text {th }}$ November & $26^{\text {th }}$ October & $18^{\text {th }}$ November \\
\hline 2. Trawling & $26^{\text {th }}$ March & $15^{\text {th }}$ April & $21^{\text {st }}$ March \\
\hline 3. Fertiliser sowing according to the diagram of experience & $19^{\text {th }}$ April & $29^{\text {th }}$ April & $8^{\text {th }}$ April \\
\hline 4. Spring tillage (tilling set) & $19^{\text {th }}$ April & $29^{\text {th }}$ April & $9^{\text {th }}$ April \\
\hline 5. Seeding - precision seeder with built-in mineral fertiliser applicator & $20^{\text {th }}$ April & $30^{\text {th }}$ April & $28^{\text {th }}$ April \\
\hline $\begin{array}{c}\text { 6. Herbicide use } \\
{ }^{1} \text { - Guardian CompleteMix } 664 \text { SE }(3.5 \text { l/ha), } \\
2 \text { - Guardian CompleteMix } 664 \text { SE }(3.5 \text { l/ha), } \\
{ }^{3} \text { - Lumax 537,5 SE (3 1/ha), } \\
{ }^{4} \text { - Nikosh 040 SC (1 1/ha) }\end{array}$ & $23^{\text {rd }}$ Apriil ${ }^{1}$ & $30^{\text {th }}$ April $^{2}$ & $\begin{array}{l}14^{\text {th }} \text { April }^{3} \\
2^{\text {th }} \text { May }^{4}\end{array}$ \\
\hline 7. Harvesting with a field harvester & $19^{\text {th }}$ October & $23^{\text {rd }}$ October & $20^{\text {th }}$ October \\
\hline
\end{tabular}

period in April, May and October and drought in July and August. Definitely the worst year in terms of moisture conditions was the last year of research, i.e. 2014. A low amount of rainfall, and simultaneous high air temperature caused a period of drought from June to October.

\section{Statistical Analysis}

Infestation of maize plants with diseases and damage by pests was determined during the period of the field experiment. Both for diseases and pests, only the number of plants that were attacked or infected by a given pathogen was recorded. The degree of disease and pest infestation was not included. Damage to maize plants by the European corn borer was determined in the wax ripe phase of the kernels (BBCH 85), by the Frit fly in the stage $\mathrm{BBCH} 15 / 16$, while the occurrence of Fusarium diseases and the common smut were determined before harvesting. The Bliss transformation was used (Arc $\sin \sqrt{\mathrm{x}}$ ) because the data had a binomial distribution expressed as a percentage $(0-20 \%)$. Fourway analysis of variance (ANOVA) was performed on the transformed data according to the experimental design. For the primary and interactive effects, significant at $\alpha=0.01$ or $\alpha=0.05$, the HSD Tukey procedure was applied (STATISTICA ver. 13).

Table 3. The average monthly air temperature and the monthly sum of atmospheric precipitation in Swadzim for the growing season.

\begin{tabular}{|c|c|c|c|c|c|c|c|c|c|c|c|c|c|c|c|c|}
\hline \multirow[b]{2}{*}{ Years } & \multicolumn{16}{|c|}{ Temperature $\left({ }^{\circ} \mathrm{C}\right)$} \\
\hline & IV & M & V & M & VI & M & VII & M & VIII & M & IX & M & $X$ & M & $\begin{array}{c}\text { Mean/ } \\
\text { Sum }\end{array}$ & M \\
\hline 2012 & 9.3 & 8.2 & 16.3 & 13.5 & 17.0 & 16.8 & 20.0 & 18.6 & 19.8 & 17.9 & 15.0 & 13.7 & 8.6 & 8.8 & 15.4 & 13.9 \\
\hline 2013 & 8.9 & 8.2 & 15.6 & 13.5 & 18.4 & 16.8 & 22.0 & 18.6 & 20.2 & 18.0 & 13.2 & 13.7 & 10.8 & 8.8 & 15.6 & 13.9 \\
\hline 2014 & 11.4 & 8.3 & 14.6 & 13.6 & 17.9 & 16.8 & 23.2 & 18.7 & 18.8 & 18.0 & 16.0 & 13.7 & 11.2 & 8.8 & 16.1 & 14.0 \\
\hline Years & \multicolumn{16}{|c|}{ Precipitation (mm) } \\
\hline 2012 & 17.4 & 32.1 & 84.4 & 52.8 & 118.1 & 56.9 & 136.2 & 75.3 & 52.7 & 58.4 & 28.4 & 43.5 & 36.4 & 37.7 & 473.6 & 356.7 \\
\hline 2013 & 10.5 & 31.8 & 95.5 & 53.4 & 114.9 & 58.0 & 52.9 & 76.5 & 32.4 & 58.3 & 75.9 & 43.2 & 15.3 & 37.7 & 397.4 & 358.9 \\
\hline 2014 & 50.3 & 31.4 & 80.7 & 54.1 & 44.6 & 59.0 & 51.5 & 76.0 & 56.5 & 57.8 & 39.2 & 43.8 & 29.0 & 37.3 & 351.8 & 359.4 \\
\hline Years & \multicolumn{16}{|c|}{ Value of hydrothermal coefficient of water preservation ${ }^{1}$} \\
\hline 2012 & 0.62 & 1.26 & 1.67 & 2.07 & 2.31 & 2.31 & 2.19 & 2.96 & 0.85 & 2.29 & 0.63 & 1.76 & 1.36 & 1.48 & 1.37 & 2.02 \\
\hline 2013 & 0.39 & 1.25 & 1.97 & 1.27 & 2.01 & 1.15 & 0.77 & 1.32 & 0.51 & 1.04 & 1.91 & 1.05 & 0.45 & 1.38 & 1.14 & 1.21 \\
\hline 2014 & 1.48 & 1.22 & 1.78 & 1.28 & 0.83 & 1.17 & 0.71 & 1.31 & 0.96 & 1.03 & 0.81 & 1.06 & 0.83 & 1.36 & 1.06 & 1.20 \\
\hline
\end{tabular}

\footnotetext{
1 - according Sielianinow [20]; M - Multiplicity (since 1958)
} 
Table 4. Infection of plants by diseases and damage of plants caused by pests and ANOVA results.

\begin{tabular}{|c|c|c|c|c|c|}
\hline \multirow{3}{*}{ Source of variation } & \multirow{3}{*}{ Df } & \multicolumn{4}{|c|}{ Mean squares } \\
\hline & & \multicolumn{2}{|c|}{ Diseases } & \multicolumn{2}{|c|}{ Pests } \\
\hline & & Fusarium diseases & Corn smut & European corn borer & Frit fly \\
\hline Blocks & 3 & 0.004977 & 0.005735 & 0.002829 & 0.003948 \\
\hline Y - Years & 2 & $1.301463 * *$ & $0.027226^{* *}$ & $0.974462 * *$ & $0.641037 * *$ \\
\hline Error 1 & 6 & 0.007943 & 0.001382 & 0.007016 & 0.004930 \\
\hline A & 1 & 0.005595 & 0.003468 & 0.003767 & 0.024999 \\
\hline $\mathrm{Y} \times \mathrm{A}$ & 2 & 0.009829 & 0.006747 & 0.000352 & 0.009151 \\
\hline Error 2 & 9 & 0.004181 & 0.054731 & 0.004131 & 0.005082 \\
\hline B & 1 & 0.004328 & 0.002655 & $0.047363 * *$ & 0.010164 \\
\hline $\mathrm{Y} \times \mathrm{B}$ & 2 & 0.006975 & 0.001289 & 0.007145 & 0.001044 \\
\hline $\mathrm{A} \times \mathrm{B}$ & 1 & 0.001019 & 0.003197 & 0.010077 & $0.032844 *$ \\
\hline $\mathrm{Y} \times \mathrm{A} \times \mathrm{B}$ & 2 & 0.001986 & 0.000587 & 0.002406 & 0.003442 \\
\hline Error 3 & 18 & 0.002117 & 0.036139 & 0.004440 & 0.004377 \\
\hline $\mathrm{C}$ & 1 & 0.001997 & $0.051060^{* *}$ & 0.001128 & $0.018613 *$ \\
\hline $\mathrm{Y} \times \mathrm{C}$ & 2 & 0.002205 & 0.004406 & 0.002887 & 0.001573 \\
\hline $\mathrm{A} \times \mathrm{C}$ & 1 & 0.001946 & 0.000779 & 0.000421 & 0.000078 \\
\hline $\mathrm{B} \times \mathrm{C}$ & 1 & 0.002697 & 0.000333 & 0.000048 & 0.000457 \\
\hline $\mathrm{Y} \times \mathrm{A} \times \mathrm{C}$ & 2 & 0.004393 & 0.000723 & $0.021568^{*}$ & 0.001623 \\
\hline $\mathrm{Y} \times \mathrm{B} \times \mathrm{C}$ & 2 & 0.001460 & 0.002091 & $0.017989 *$ & 0.001844 \\
\hline $\mathrm{A} \times \mathrm{B} \times \mathrm{C}$ & 1 & 0.006004 & 0.004584 & 0.000788 & 0.004875 \\
\hline $\mathrm{Y} \times \mathrm{A} \times \mathrm{B} \times \mathrm{C}$ & 2 & 0.005348 & 0.007782 & 0.002226 & 0.004956 \\
\hline Error 4 & 36 & 0.003129 & 0.002475 & 0.005112 & 0.004099 \\
\hline
\end{tabular}

** - significant at $\mathrm{p}$-value $<0.01, *$ - significant at $\mathrm{p}$-value $<0.05$

\section{Results and Discussion}

As a result of three-year (2012-2014) studies, it was found (Tables 4-5) that regardless of the method of sowing maize, the cultivar used and the method of applying NP fertiliser, significantly the largest damage to plants caused by the studied diseases occurred in 2013 (Fusarium diseases, 16.21\%) and in 2013 and 2014 (Corn smut, $0.809 \%$ and $0.807 \%$ ). The results presented in the current study have confirmed earlier literature reports that the occurrence of fungi of the genus Fusarium ssp. is dependent on variable environmental conditions in individual growing seasons [21, 22]. It was observed that in 2012 the damage caused by both diseases was significantly the smallest. There was not found any significant impact of the experimental factors and their interactions on the degree of plant infection in 2012-2014, with one exception. It was noted (Table 5) that, regardless of the study year, the method of sowing maize and the cultivar used, Corn smut damaged plants more heavily $(\alpha=0.01)$ when NP fertiliser was applied before sowing the seeds $(0.913 \%)$.
On the other hand, it was shown in another author's work [23] that the method of spreading the fertiliser did not have a significant impact on the percentage of plants infected by common smut. According to Beresia and Pruszyńskiego [24], common smut currently is and will be in the coming years one of important maize diseases. As a result of the three-year field experiments mentioned above, it was found (Table 4, Table 6) that regardless of the experimental factors, the largest plant damage caused by both pests occurred in 2014. In turn, significantly the smallest damage was caused by the Frit fly in $2012(0.37 \%)$, and by the European corn borer in 2012 and 2013 (1.39\% and $0.98 \%$ respectively). In our own research, however, there was no significant effect of the maize sowing method (A) on plant damage caused by either pest, regardless of the year of research or in interaction with years (Table 4). Also, regardless of the study year and the method of sowing maize, the greatest damage to plants caused by the European corn borer was recorded for the fast maturing cultivar (6.55\%). Szulc [25] also demonstrated that the "stay-green" hybrid had significantly lower susceptibility to feeding 
Table 5. Mean values of infection of plants by diseases.

\begin{tabular}{|c|c|c|c|c|c|}
\hline \multirow{2}{*}{ Factors } & \multirow{2}{*}{ The levels } & \multicolumn{2}{|c|}{ Fusarium diseases } & \multicolumn{2}{|c|}{ Corn smut } \\
\cline { 2 - 6 } & & $(\%)$ & ${ }^{\circ}$ Bliss & $(\%)$ & ${ }^{\circ}$ Bliss \\
\hline \multirow{3}{*}{$Y$} & 2012 & 0.19 & $0.013^{\mathrm{c}}$ & 0.130 & $0.011^{\mathrm{b}}$ \\
\cline { 2 - 6 } & 2013 & 16.21 & $0.411^{\mathrm{a}}$ & 0.809 & $0.058^{\mathrm{a}}$ \\
\cline { 2 - 6 } & 2014 & 7.52 & $0.269^{\mathrm{b}}$ & 0.807 & $0.064^{\mathrm{a}}$ \\
\hline \multirow{3}{*}{$\mathrm{C}$} & $\mathrm{C} 1$ & 7.60 & $0.227^{\mathrm{a}}$ & 0.913 & $0.067^{\mathrm{a}}$ \\
\cline { 2 - 6 } & $\mathrm{C} 2$ & 8.35 & $0.236^{\mathrm{a}}$ & 0.251 & $0.021^{\mathrm{b}}$ \\
\hline
\end{tabular}

Values in columns marked with at least the same letter do not differ significantly $(\alpha=0.01)$

Table 6. Mean values of damage of plants caused by pests.

\begin{tabular}{|c|c|c|c|c|c|}
\hline \multirow{2}{*}{ Factors } & \multirow{2}{*}{ The levels } & \multicolumn{2}{|c|}{ European corn borer } & \multicolumn{2}{|c|}{ Frit fly } \\
\hline & & $(\%)$ & ${ }^{\circ}$ Bliss & $(\%)$ & ${ }^{\circ}$ Bliss \\
\hline \multirow{3}{*}{$\mathrm{Y}$} & 2012 & 1.39 & $0.094^{b}$ & 0.37 & $0.021^{\mathrm{c}}$ \\
\hline & 2013 & 0.98 & $0.072^{b}$ & 2.50 & $0.143^{b}$ \\
\hline & 2014 & 14.54 & $0.384^{\mathrm{a}}$ & 9.37 & $0.303^{\mathrm{a}}$ \\
\hline \multirow{2}{*}{$\mathrm{B}$} & B1 & 6.55 & $0.205^{\mathrm{a}}$ & 4.48 & $0.166^{\mathrm{a}}$ \\
\hline & B2 & 4.73 & $0.161^{b}$ & 3.68 & $0.145^{\mathrm{a}}$ \\
\hline \multirow{2}{*}{$\mathrm{C}$} & $\mathrm{C} 1$ & 5.66 & $0.187^{\mathrm{a}}$ & 4.77 & $0.169^{\mathrm{a}}$ \\
\hline & $\mathrm{C} 2$ & 5.62 & $0.180^{\mathrm{a}}$ & 3.39 & $0.142^{b}$ \\
\hline
\end{tabular}

Values in columns marked with at least the same letter do not differ significantly ( $\alpha=0.01$ or 0.05 )

of the European corn borer compared to the traditional cultivar. Szulc [26] showed a high positive correlation coefficient between the occurrence of European corn borer and the infestation of maize plants by Fusarium spp. However, the cultivar used did not differentiate the percentage of damage done by the Frit fly (Table 6). At the same time (Table 4), significant interaction of varieties and methods of sowing maize was recorded for this pest (regardless of the year of research). It was found (Fig. 1) that, comparing both methods of maize sowing and both varieties, the Frit fly more heavily damaged plants of the fast maturing cultivar when direct sowing to stubble was used (6.04\%). For the "stay-green" type, the method of soil preparation for sowing did not significantly affect the pressure of this pest. The obtained result confirms previous literature reports that "stay-green" cultivars are characterized by a stronger root system [27]. According to these authors, "stay-green" maize varieties are characterized by a more dynamic root system development during juvenile stages compared to the traditional hybrid. Hence, the simplified method of soil preparation for maize sowing should give preference to cultivating the "stay-green" cultivar. Mahalakshmi and Bidinger [14] also found that the "stay-green" varieties are more tolerant to stress conditions, such as soil compaction in which plants are more susceptible to pathogens. In our own research, regardless of the year, the method of sowing maize and the cultivar, the greatest crop damage was caused by the Frit fly when the method of applying NP fertiliser before seed sowing (4.77\%) was used. On the other hand, the method of NP fertiliser application did not differentiate the percentage of plants damaged by the European corn borer (Table 6). It was also observed (Table 7) that regardless of the cultivar, the greatest damage caused by this pest

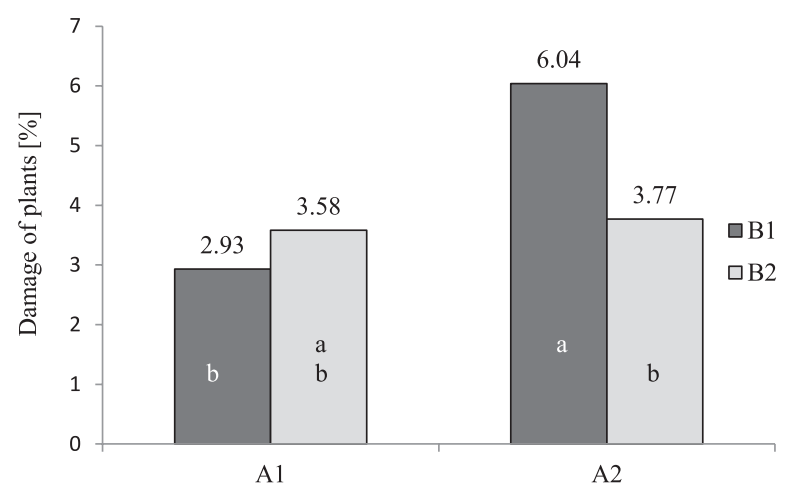

Fig. 1. Mean values of damage of plants caused by frit fly for the combination of two methods of maize sowing (A) and two types of cultivars (B). a, b-homogeneous groups $(\alpha=0.05)$ 
Table 7. Mean values of damage of plants caused by European corn borer for the combination $Y \times A \times C$.

\begin{tabular}{|c|c|c|c|c|c|c|c|}
\hline \multirow{3}{*}{ A } & \multirow{3}{*}{$\mathrm{C}$} & \multicolumn{6}{|c|}{ Years (Y) } \\
\hline & & \multicolumn{2}{|c|}{2012} & \multicolumn{2}{|c|}{2013} & \multicolumn{2}{|c|}{2014} \\
\hline & & $(\%)$ & ${ }^{\circ}$ Bliss & $(\%)$ & ${ }^{\circ} \mathrm{Bliss}$ & $(\%)$ & ${ }^{\circ}$ Bliss \\
\hline \multirow{2}{*}{ A1 } & $\mathrm{C} 1$ & 0.91 & $0.067^{b}$ & 1.02 & $0.086^{\mathrm{b}}$ & 14.26 & $0.382^{\mathrm{a}}$ \\
\hline & $\mathrm{C} 2$ & 1.68 & $0.110^{\mathrm{b}}$ & 0.67 & $0.050^{\mathrm{b}}$ & 13.06 & $0.367^{\mathrm{a}}$ \\
\hline \multirow{2}{*}{$\mathrm{A} 2$} & $\mathrm{C} 1$ & 2.33 & $0.141^{b}$ & 1.16 & $0.072^{\mathrm{b}}$ & 14.27 & $0.372^{\mathrm{a}}$ \\
\hline & $\mathrm{C} 2$ & 0.65 & $0.056^{\mathrm{b}}$ & 1.06 & $0.079^{b}$ & 16.59 & $0.417^{\mathrm{a}}$ \\
\hline
\end{tabular}

Values in columns marked with at least the same letter do not differ significantly $(\alpha=0.05)$

Table 8. Mean values of damage of plants caused by European corn borer for the combination $\mathrm{Y} \times \mathrm{B} \times \mathrm{C}$.

\begin{tabular}{|c|c|c|c|c|c|c|c|}
\hline \multirow{3}{*}{ B } & \multirow{3}{*}{$\mathrm{C}$} & \multicolumn{6}{|c|}{ Years (Y) } \\
\hline & & \multicolumn{2}{|c|}{2012} & \multicolumn{2}{|c|}{2013} & \multicolumn{2}{|c|}{2014} \\
\hline & & $(\%)$ & ${ }^{\circ} \mathrm{B}$ liss & $(\%)$ & ${ }^{\circ}$ Bliss & $(\%)$ & ${ }^{\circ}$ Bliss \\
\hline \multirow{2}{*}{ B1 } & $\mathrm{C} 1$ & 1.44 & $0.084^{\mathrm{b}}$ & 1.58 & $0.112^{\mathrm{b}}$ & 17.69 & $0.433^{\mathrm{a}}$ \\
\hline & $\mathrm{C} 2$ & 1.54 & $0.115^{\mathrm{b}}$ & 1.11 & $0.081^{\mathrm{b}}$ & 15.92 & $0.408^{\mathrm{a}}$ \\
\hline \multirow{2}{*}{ B2 } & $\mathrm{C} 1$ & 1.80 & $0.124^{\mathrm{b}}$ & 0.60 & $0.047^{\mathrm{b}}$ & 10.84 & $0.321^{\mathrm{a}}$ \\
\hline & $\mathrm{C} 2$ & 0.78 & $0.051^{\mathrm{b}}$ & 0.62 & $0.048^{\mathrm{b}}$ & 13.73 & $0.376^{\mathrm{a}}$ \\
\hline
\end{tabular}

Values in columns marked with at least the same letter do not differ significantly $(\alpha=0.05)$

occurred in 2014, while the combination of the method of maize sowing and the method of fertiliser application did not cause significant differences between the percentages of plant damage within that year. It was also noted (Table 8) that irrespective of the method of sowing maize, significantly the greatest damage was caused by the European corn borer in 2014, and the combination of maize varieties and NP fertiliser application methods within that year and the other years of research did not differentiate the degree of damage caused by this pest.

\section{Conclusions}

1. The percentage of plants damaged by pests or affected by diseases showed a variable response to weather conditions and experimental factors.

2. The positive effect of the row method of NP fertiliser application in maize cultivation not only reduced plant infestation by Fusarium diseases, but also reduced the Frit fly pressure.

3. The "stay-green" hybrid was characterized by a significantly lower susceptibility to feeding of the European corn borer compared to the traditional cultivar.

4. Sowing maize of the traditional cultivar using the direct sowing system increased damage to plants by Frit fry larvae compared to sowing into soil cultivated in a traditional way. For the "stay-green" type, the method of soil preparation for sowing did not significantly affect the pressure of this pest.

5. Cultivation of "stay-green" hybrid such may be considered as an element of integrated maize production.

\section{Conflict of Interest}

The authors declare no conflict of interest.

\section{References}

1. DONATELLI M., MAGAREY R.D., BREGAGLIO S., WILLOCQUET L., WHISH J.P.M., SAVARY S. Modelling the impacts of pests and diseases on agricultural systems. Agricultural Systems, 155, 213, 2017.

2. METZGER M.J., BUNCE R.G.H., JONGMANN R.H.G., MÜCHER C.A., WATKINS J.W. A climatic stratification of the environment of Europe. Global Ecology Biogeography, 14, 549, 2005.

3. LIPIEC J., WALCZAK R., WITKOWSKA-WALCZAK B., NOSALEWICZ A., SŁOWIŃSKA-JURKIEWICZ A., SŁAWIŃSKI C. The effect of aggregate size on water retention and pore structure of two silt loam soils of different genesis. Soil \& Tillage Research, 97, 239, 2007.

4. BRONICK C.J., LAL R. Soil structure and management: a review. Geoderma, 124, 3, 2005.

5. SINGH M.J., KHERA K.L. Physical indicators of soil quality in relation to soil erodibility under different land use. Arid Land Research Management, 2, 152, 2009. 
6. CZYŻ E.A. Effects of traffic on soil aeration, bulk density and growth of spring barley. Soil \& Tillage Research, 79, 153, 2004

7. REYNOLDS W.D., DRURY C.F., YANG X.M., TAN C.S, Optimal soil physical quality inferred through structural regression and parameter interaction. Geoderma, 146, 466, 2008.

8. MI G., LIU J., CHEN F., ZHANG F., CUI Z., LIU X. Nitrogen uptake and remobilization in maize hybrids differing in leaf senescence. Journal of Plant Nutrition, 26 (1), 237, 2003.

9. SINCLAIR T.R., RUFTY W.T. Nitrogen and water resources commonly limit crop yield increases, not necessarily plant genetics. Global Food Security, 1, 94, 2012.

10. SUBEDI K.D., MA B.L. Nitrogen uptake and partitioning in stay-green and leafy maize hybrids. Crop Science, 4, 740, 2005.

11. KRAUSS A. Potassium and biotic stress. Proc. FaubaFertilizer-IPI workshop on potassium in Argentina's agricultural system. Buenos Aires, Argentyna, 2001.

12. BOCIANOWSKI J., SZULC P., WAŚKIEWICZ A., NOWOSAD K., KOBUS-CISOWSKA J. Ergosterol and Fusarium mycotoxins content in two maize cultivars under different forms of nitrogen fertilizers. Journal of Phytopathology, 167, 516, 2019.

13. SZULC P., BOCIANOWSKI J., RYBUS-ZAJĄC M. Accumulation of $\mathrm{N}, \mathrm{P}, \mathrm{K}$ and $\mathrm{Mg}$ nutrient elements and nutrient remobilization indices in the biomass of two contrasting maize (Zea mays L.) hybrids. Fresenius Environmental Bulletin, 21 (8), 2062, 2012.

14. MAHALAKSHMI V., BIDINGER F.R. Evaluation of stay green sorghum germplasm lines at ICRISAT. Crop Sciences, 42, 965, 2002.

15. BÄNZIGER M., EDMEADES G.O., LAFITTE H.R. Physiological mechanisms contributing to the increased $\mathrm{N}$ stress tolerance of tropical maize selected for drought tolerance. Field Crop. Research, 75, 223, 2002.

16. CIAMPITTY A.I., VYN J.T. Physiological perspectives of changes over time in maize yield dependency on nitrogen uptake and associated nitrogen efficiencies: a review. Field Crop Research, 133, 48, 2012.

17. SZULC P., BOCIANOWSKI J., NOWOSAD K., MICHALSKI T., WALIGÓRA H., OLEJARSKI P. Assessment of the influence of fertilization and environmental conditions on maize health. Plant Protection Science, 54 (3), 174, 2018.

18. CAUBEL J., LAUNAY M., RIPOCHE D., GOUACHE D., BUIS S., HUARD F., HUBER L., BRUN F., BANCAL M. Climate change effects on leaf rust of wheat: Implementing a coupled crop disease model in a French regional application. European Journal of Agronomy, 90, 53, 2017.

19. NEWBERY F., QI A., FITT B.D.L. Modelling impacts of climate change on arable crop diseases: progress, challenges and applications. Current Opinion in Plant Biology, 32, 101, 2016.

20. SZULC P., JAGŁA M., NOWOSAD K., BOCIANOWSKI J., OLEJARSKI P. Path analysis in assessment of cause and effect dependencies of yield structure components in maize cultivars differing in genetic profiles. Fresenius Environmental Bulletin, 26 (12), 7309, 2017.

21. SCAUFLAIRE J., MAHIEU O., LOUVEAUX J., FOUCART G., RENARD F., MUNAUT F. Biodiversity of Fusarium species in ears and stalks of maize plants in Belgium. European Journal Plant Pathology, 131, 59, 2011.

22. MESTERHÁZY Á., LEMMENS M., REID L.M. Breeding for resistance to ear rots caused by Fusarium ssp. in maize - a review. Plant Breeding, 131, 1, 2012.

23. SZULC P., RYBUS-ZAJĄC M., JAGŁA M. Influence of nitrogen dose, type of nitrogen fertilizer and method of its application on plant health of maize hybrids (Zea mays L.). EJPAU, 17 (2), \#10, 2014.

24. BEREŚ K.P., PRUSZYŃSKI G. Pest management in integrated maize production. Acta Scientiarum Polonorum, Agricultura, 7 (4), 19, 2008 [In Polish].

25. SZULC P. Occurrence of European corn borer (Ostrinia nubilalis $\mathrm{Hbn}$.) depending on soil content of nitrogen and a form of nitrogen fertilizer. Progress in Plant Protection/ Postępy w Ochronie Roślin, 53 (1), 74, 2013a [In Polish].

26. SZULC P. Organic and mineral fertilization of maize affecting prevalence of fusarium diseases (Fusarium spp.) and European corn borer (Ostrinia nubilalis Hbn.). Progress in Plant Protection/Postępy w Ochronie Roślin, 53 (3), 498, 2013b [In Polish].

27. SZULC P., BOCIANOWSKI J. Susceptibility of maize hybrids (Zea mays L.) to frit fly (Oscinella frit L.) under conditions of diversified nitrogen content in the soil and different types of nitrogen fertilizers. Acta Scientiarum Polonorum seria Agricultura, 13 (2), 63, 2014. 
